\title{
VERDES-FORA E PROJETOS PARTICIPATIVOS: A BUSCA PELA SUSTENTABILIDADE EM BAIRROS HABITACIONAIS SOCIAIS
}

\section{Verônica Lombardi Silva*, Silvia Mikami Pina, Evandro Z. Monteiro \\ velombardi@hotmail.com; silviaunicamp@gmail.com; evandrozigfec@gmail.com \\ Resumo}

As cidades brasileiras caracterizam-se por bairros da população carente constituídos pela moradia autoconstruída em territórios periféricos da malha urbana. Neles, é comum a degradação dos recursos naturais e da qualidade socioambiental, principalmente nas suas áreas abertas e públicas. Esta pesquisa avalia os efeitos da iniciativa de processo participativo realizado pelo DATAHABIS/Finep na qualidade ambiental do bairro Residencial São José em Campinas dez anos após sua implantação. Para isso, foram realizadas visitas técnicas ao bairro para observação de como os moradores se apropriaram dos verdes-fora, com registros gráficos e fotográficos e entrevistas de avaliação com moradores-chave. Os resultados indicam uma apropriação ampla da arborização e da apropriação de áreas públicas destinadas a praças, mesmo sem a iniciativa do poder público, apontando autonomia dos moradores. A análise dos resultados fomentou estratégias de projeto urbano de bairros habitacionais sociais, tanto na perspectiva da sustentabilidade urbana quanto dos processos participativos.

Palavras-chave: Habitação de Interesse Social, espaços abertos, sustentabilidade urbana.

\section{Introdução}

A malha urbana espraiada e fragmentada tem sido a característica de grande parte das cidades brasileiras. Este padrão tem exercido uma pressão sobre os recursos naturais e a qualidade socioambiental dos bairros de moradia da população carente. Esse conflito levou um grupo de pesquisadores da FEC-UNICAMP a trabalhar a qualidade socioambiental dos espaços abertos em bairro habitacional autoconstruído junto com seus moradores, entre 2006-2008, por meio do projeto DataHabis $^{1}$ que realizou oficinas participativas com os moradores. Dez anos após a implantação da pesquisa, este trabalho retornou ao bairro para avaliar seus efeitos sobre a apropriação dos verdes-fora (praças, calçadas, canteiros, recuos) pelos moradores. 0 Residencial São José fica na região sudoeste de Campinas e seu projeto urbano é da Cohab-Campinas, dentro do programa de Lotes Urbanizados. Foram realizadas diversas visitas técnicas ao bairro para levantamento e mapeamento do atual uso e estado das áreas abertas e verdes-fora, além de entrevistas aos moradores do bairro.
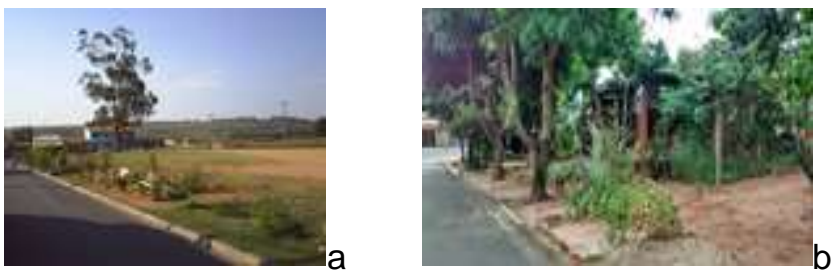

Figura 1. Residencial São José- Praça 1 antes (a) e depois (b) da pesquisa. Fonte: arquivo das autoras.

\section{Resultados e Discussão}

As imagens da Fig.1 apresentam com bastante clareza a apropriação do espaço aberto público pelos moradores do Residencial São José. Originalmente, o bairro era bastante árido, quente e quase sem vegetação, sem praças e equipamentos urbanos além da única escola de ensino fundamental. Hoje, o bairro encontra-se muito arborizado, especialmente nas duas praças, construídas e mantidas inteiramente pelos moradores. A Praça 1, manteve a pista de jogo de bocha, agora coberta, com bancos e mesas, um pequeno centro comunitário e muitas árvores e flores plantadas, além de uma extensa horta comunitária. Próxima a praça1, os moradores construíram também um campo de areia para jogos, cercado com alambrado e com vestiários. A praça 2 , ao lado dos trilhos, ampliou-se e em toda sua extensão há jardins, árvores frutíferas, bancos e mesas, churrasqueira $O$ pergolado de madeira, construído coletivamente um com a comunidade em uma das oficinas, hoje se encontra integrado com as demais árvores da praça. Por todo o bairro há árvores nas calçadas e recuos, contribuindo para um melhor conforto térmico. Recentemente, foi construída a creche, complementando o equipamento escolar. A densidade construtiva, entretanto, aumentou consideravelmente, com casas ampliadas para 2 e 3 pavimentos.

\section{Conclusões}

Os resultados explicitam que as oficinas promovidas pelo projeto DataHabis contribuíram para destacar a importância da vegetação para o conforto térmico e paisagem do bairro. $O$ zelo, o interesse e a dedicação dos moradores em manter as áreas abertas após o término do projeto é fator positivo e reforça a importância de processos participativos entre a universidade e a cidade. Fica evidente, contudo, a ausência do poder público na implantação de praças, jardins e desenho urbano de qualidade nos bairros habitacionais de periferia e a necessidade de apoio que tais locais requerem.

(1)Difusão e Aplicação de Tecnologia em Áreas Habitacionais de Interesse Social para construção de Ambientes Saudáveis e Sustentáveis em Campinas_ com apoio da FINEP 